\title{
Digital Marketing Strategy to Increase Brand Awareness and Customer Purchase Intention (Case Study: Ailesh Green Consulting)
}

\author{
Dwiana Rahmadiati Putri
}

\section{ABSTRACT}

\begin{abstract}
Ailesh Green Consulting is an environmental consulting service with the target is a company that produces waste, especially companies that are included in the gold criteria in PROPER. The main problem is having low brand awareness and the low of customer purchase intention from target customers to use their services. The research methodology uses qualitative research. This research aims to help raise brand awareness and customer purchase intention of their potential customers. The data was collected using an interview system with 10 respondents who had a background in the environmental field, working for companies that are under gold criteria in PROPER. Based on the result, respondents' brand awareness is low, as well as the customer purchase intentions. It was found the digital media recommended to use for the company by the respondents is display advertising, LinkedIn social media, search engines, and websites. Based on the results, Ailesh Green Consulting is able to optimize Search Engine Optimization (SEO) supported by an attractive website optimizer and content marketing website, create and optimize the use of LinkedIn social media, and use of LinkedIn ads.
\end{abstract}

Keywords: Brand Awareness, Consultant, Content Marketing, Customer Purchase Intention, Digital Marketing, Display Advertising, Search Engine Optimization, Social Media Marketing.

\author{
Submitted : August 19, 2021 \\ Published : September 12, 2021 \\ ISSN: $2507-1076$ \\ DOI: $10.24018 / \mathrm{ejbmr} .2021 .6 .5 .1063$ \\ Dwiana Rahmadiati Putri* \\ Master of Business Administration, \\ Institut Teknologi Bandung, Bandung, \\ West Java, Indonesia. \\ (e-mail: \\ dwiana_rahmadiati@sbm-itb.ac.id)
}

\section{INTRODUCTION}

Digital marketing is a marketing strategy that a company needs for the current era. A company needs a marketer with up-to-date knowledge about digital marketing works and their application, such as on a website, email, mobile, and interactive TV [1].

One of the factors that have accelerated the change in strategic marketing to digital marketing strategy is the covid19 pandemic, where Indonesians are encouraged to stay at home until the covid-19 pandemic ends, as well as government policies related to the pandemic, namely keeping your distance, and no crowding, which causes offline sales moved to online sales. This statement is supported by data from [2] in 2020 Q2, which states that internet users in Indonesia are 196.71 million of the total Indonesian population of 266.91 million, or as many as $73.7 \%$ of Indonesians already use the internet in their daily lives. Internet users in Indonesia increased by $8.9 \%$ or $25,537,353.5$ people. [3], which states that digital advertising spending in Indonesia through classifieds such as video advertising, social media advertising, banner advertising, search advertising increased in 2020 due to the impact of Covid-19, it is predicted to increase by around IDR 21 billion or increase $15.15 \%$ year on year compared to March 2019 which reached IDR 18 billion.

Businesses that use digital marketing are not the only business to consumers but also business to business. For business-to-business data, it is supported by open rate data for email marketing in Indonesia shows that the b2b company industry has the most significant percentage of average open rate marketing email in Indonesia, which is $38.56 \%$. Next is data regarding a company's click-through rate (CTR), which is data on the percentage of people who click on a link in an email; this is one way to determine whether consumers are interested and see the document sent or not. The business-tobusiness company industry is the second most significant percentage with 7,65\% [4]. From these two data, it indicates that digital marketing (via email marketing) is a step that shows the Indonesian people have started to show an interest in the digital marketing world, but the effectiveness still needs to be done more in-depth research.

This increasing use of the internet occurs in all lines of business, from small-scale to large-scale businesses. This massive shifting in Indonesia has a significant impact on the economy, especially for businesses that are less able to adapt to change will slowly be displaced and will go bankrupt in this pandemic. A business or company must change to the digital world, turning all-access, which was initially in the form of offline services or products, into online services or products. To compete in this digital world, according to what [1] have said, a business needs marketers who can adapt, one of which is by changing to digital marketing. All lines of business (both in products and services) require digital marketing, including the object that the authors chose, a business that uses a business-to-business system, namely Ailesh Green Consulting, a consulting service for environmental impact control and improvement. 


\section{LITERATURE REVIEW}

\section{A. Digital Marketing}

Digital marketing is any marketing method through electronic devices, this is an ever-changing, and dynamic process. Unlike the traditional way where communication is only one way, but digital marketing required two-way communication, where the prospective customers can interact with the business [1]. Digital marketing is reaching the marketing objectives through digital technologies and media includes managing the presence of the business online, such as company website and social media. [2]. Digital marketing is an approach, terms, or strategy of branding used by digital platforms to achieve marketing objectives [3].

\section{B. Search Engine Optimization}

When consumers type a keyword in search engines, they trust organic links more, advertisers try to show their website by gaming with logarithmic rankings on search engines socalled Search Engine Optimization [4]. Search Engine Optimization is a method, tool, tactic used to raise visitors into a website by obtaining high-ranking placement on the search engines [5]. Search Engine Optimization increases the opportunity of customers to discover the website [6]. Search Engine Optimization has always involved a combination of techniques to ensure pages are indexed, development of content, and working with site owners, to encourage people to click-through to a website using a specifics keyword [2]. SEO always focuses on optimizing for the user, not the search engine [7]. Digital marketing communications tools such as Search Engine Optimization (SEO) or paid keywords makes the company play active roles instead of passive roles in the process of creating brand awareness and the consumers become more interactive in the marketing process [8], it also as marketing tools has a significant impact to the customers, enhance the brand equity which is consist of brand commitment, brand loyalty, brand image, and brand awareness [9] an effective tools to increase and improving brand awareness, because it helps to increase the ranking on the webpage [5].

\section{Social Media Marketing}

Social media marketing can reach many customers at a low cost. Influencers in social media can have a significant impact on the brand [2]. Social media marketing has a direct and positive impact on brand awareness. Social media marketing is the second most powerful impact on brand awareness after the mobile channel [10]. Social media marketing has a positive and significant impact on brand awareness proven by there is a positive correlation and significant relationship [11]. Social media marketing affects the consumer purchase intention, because it allows two ways of communication between the company and the customers, it is creating a positive impact [15] This is support by the studies from [12], stated that social media marketing has a significant impact to purchase intention. Consumers make a purchase decision based on information on social media, and consumers, these social media to share the information with others.

\section{Content Marketing}

Digital content marketing was proposed to capture the use of digital content to drawing $\mathrm{B} 2 \mathrm{~B}$ customers to their space (for example, website) and promoting ongoing interaction and engagement with the brand. It also involves creating, distributing, and sharing relevant content to engage customers at the point of the potential customers buying consideration process [13]. Content marketing is the management of text, rich media, audio, and video content aimed to engage the customers to meet the business goals published through print and digital media including the website [2].

\section{E. Display Advertising}

Use of online ads such as banners and rich media ads to achieve brand awareness and encourage people to clickthrough to a target site [14]. Brand or product-related visual content created by a brand, payment for the placement in time and space is made [15].

\section{F. Brand Awareness}

Brand awareness means being aware of brand existence and its relationship with a particular product [16]. Brand awareness is a capacity or given customer to recognize or recall the brand, belongs to a particular product [17], and as a fundamental and foremost limitation in any brand-related search and the ability of a customer to recognize and recall the brand in any kind of situations [18]. Brand awareness plays the main role in consumer decisions making [19].

\section{G. Customer Purchase Intention}

Purchase intentions mean a customer's plan to buy a good or attain a service, it refers to the desire of customers to buy a product or service from a brand. Customer purchase intentions depend on the level of satisfaction, that the customers expect and receive [18]. Customer purchase decision will be the most preferred brand, with the two factors in between the purchase intention and purchase decisions [20]. The five sub decisions to make a purchase intention are brand, dealer, quantity, timing, and payment. Two general factors can intervene in the purchase intention, the first is the attitudes of others. The more intense the other's person negativism and the closer the consumers to the brand, the more they will adjust to purchase decisions. The second factor is unanticipated situational factors, that may erupt the purchase intentions [21].

\section{CONCEPTUAL FRAMEWORK}

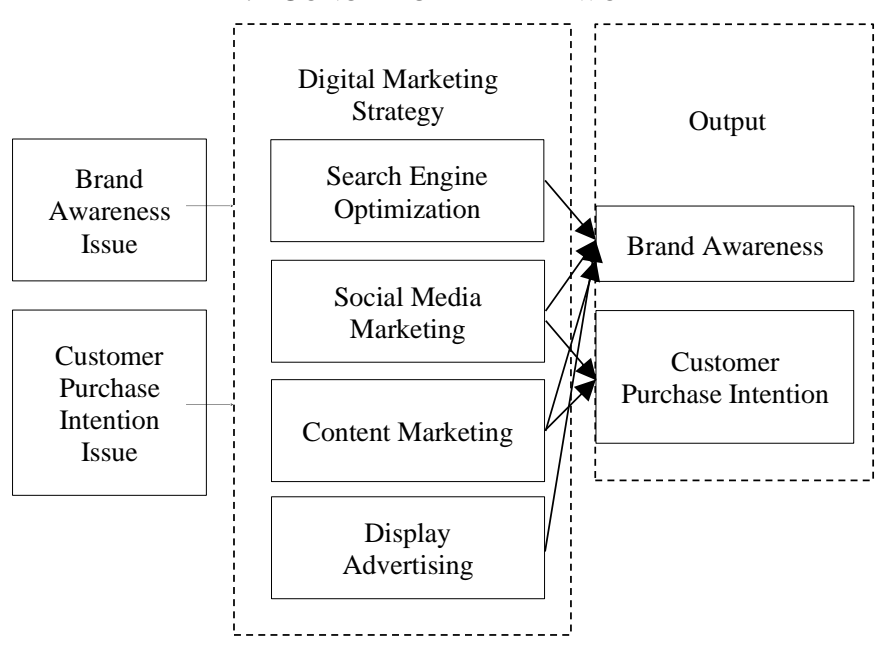

Fig. 1 Conceptual Framework. 


\section{RESEARCH METHOD}

For this research, the author uses a qualitative research approach. Qualitative research relies on theories of social sciences and the humanities to research and guide the findings of research [22]. A method by which data is collected and where theory evolves during the research process [23]. Authors use primary and secondary data collection that supports each other so that they can provide comprehensive and appropriate analysis results.

The primary data was collected by interviewing the Chief of Business Officer of Ailesh Green Consulting, to understand the current problems and company description. The secondary data was collected by interviewing the ten respondents who work as a Health, Safety, and Environment division in a company working for companies that are included in the lists of Gold PROPER (Company Performance Rating Program in Environmental Management) which is the main target of Ailesh Green Consulting. The interview was conducted to ensure that the problems experienced by Ailesh Green Consulting are the main concern that is felt by target customers, as well as knowing more about digital marketing platforms or tools that suit customers, which will be the main strategy of research.

\section{Result}

\section{A. The Current Problem Faced by Ailesh Green Consulting}

Based on interviews with CBO Ailesh Green Consulting, they have an issue related to customer purchase intention, namely the desire of consumers to buy products from Ailesh Green Consulting is low, brand awareness is low because the age of the company is still new (established in 2020), so many potential customers who do not know about Ailesh Green Consulting as an LCA analysis service. However, both issues still have to be confirmed through surveys conducted by the author on potential customers or target markets targeted by Ailesh Green Consulting.

\section{B. Customer Understanding about Life Cycle Assessment}

The author has surveyed the target market of Ailesh Green Consulting on consumer understanding of LCA Analysis with a few questions. Based on the respondent's answer, the author obtained information about the respondent's understanding of LCA, on the survey obtained results that seven out of ten respondents stated that they know and know that LCA documents are an obligation owed by the company they currently work for. However, two out of ten respondents said they still did not know that the LCA was a document required by the government from 2021. Respondents know LCA documents from various sources, namely colleagues, companies, social media, PROPER, training, socialization from the Minister of Environment and Forestry of the Republic of Indonesia, and webinars.

\section{Customer Purchase Intention}

Based on the results of the survey with respondents, they stated that they are not interested in using Ailesh Green Consulting services in the future. Nine out of ten stated that they are not intended to use Ailesh Green Consulting as their LCA document provider for their company. Most of them said that this decision cannot be defined by personal because it should be studied more deeply by a team appointed by the company such as HSE as a whole department.

\section{Digital Marketing}

Based on the results of a survey with ten respondents, most of them started using laptops and mobile phones as the devices they use to find information. Media websites, social media, digital advertisement, and search engines they use to search for information. While the most undesirable media by respondents is email marketing because email marketing is usually routinely sent every few times, so they feel annoyed by it, but if the company only sends email marketing occasionally, the respondent will not see or know the email. If they want to look for a partner in business, mostly they will find it on social media Linked In, websites, and search engines. The most suitable media for Ailesh Green Consulting based on the respondents is the website, social media, and search engine. Most of them said that there is the probability of using Ailesh Green Consulting if Ailesh Green Consulting using media which they convenient with.

\section{DISCUSSION}

The analysis was conducted based on the main problem of Ailesh Green Consulting, namely brand awareness issue and customer purchase intention issue. The author proposed four solutions to Ailesh Green Consulting to enhance their brand awareness and customer purchase intention, based on the questionnaire.

\section{A. Search Engine Optimization}

SEO to be used using white hat techniques, the ethical techniques that follow search engines' rules and policies. The technique search engine returns quality content. These techniques benefit both parties, users, and also search engines [24]. Search Engine Optimization has two majors, the first one is on-page optimization and the second is off-page optimization [25]. The factors of on-page optimization and off-page optimizations are as follows:

\section{1) On-Page Optimization}

\section{a. Keyword Research}

Search for keywords relevant to the theme of the website [25]. Based on interviews with ten respondents, they stated that they used keywords; LCA Indonesia, LCA Indonesian consultants, LCA Services, LCA Services Indonesia, LCA as their keywords to search about Life Cycle Assessment consultants.

\section{b. Title Tag}

It informs the search engine about the theme of the website [25]. The application for the title tag, based on their services on Life Cycle Assessment so that the title tag used is Ailesh Green Consulting - Life Cycle Assessment (LCA) Consulting.

\section{c. Description Meta Tag}

Description meta-tag is explaining a web page or website [25]. The description meta tag on Ailesh Green Consulting is "Ailesh Green Consulting is a partner for companies that are committed to supporting environmental improvement efforts. With the main focus on Life Cycle assessment, Ecoefficiency optimization, energy, and environmental audits". 


\section{d. Optimized URL}

The URL of the website must be readable, simple, selfexplanatory [25]. For the URL of Ailesh Green Consulting, because they already have a website, so the URL used will remain the same because it already symbolizes their brand as a subsidiary and explains that they are under Ailesh power. The intended URL is http://agc.aileshpower.com/.

\section{e. Content}

The main content should describe the idea of the website [25]. The use of the content for on-page optimization is as follows based on [26]:

\section{f. Title/ Headline}

This is the first thing potential visitors will view. It should use words or phrases that people use often on a web search. Using proper names and locations is also recommended. The most important aspect is the headline should be clear, unique, and descriptive.

Title: Life Cycle Assessment (LCA), an important assessment for your company!

\section{g. Different titles/ headlines}

Using a different headline for dissimilar use for the same story or content. Different title: Life Cycle Assessment for your company!

\section{h. First paragraph}

Targeted keywords should be included naturally in the first paragraph of the content. The earlier uses the keyword, the more considered to be relevant to a search using the keyword. In the first paragraph, usually answer about who, when, where. First paragraph: Ailesh Green Consulting is one the consulting company for LCA in Indonesia, which filled with young people who has a professional experience in Life Cycle Assessment.

\section{i. Video (or multimedia) content}

Video contents attract and engage potential visitors more since it is highly shareable than the traditional text results. This is a valuable tool to reach more audiences and get traffic. Video: about Life Cycle Assessment on 13 power plants analyzed by Ailesh Green Consulting. A short video on how to analyze, the process, and the result.

\section{j. Content marketing and Qualitative content}

Professional quality content is still necessary. Users know good content and will likely share about it through their social networks, blog, or forum. Content that Ailesh Green Consulting should talk about is content about education such as understanding about Life Cycle Assessment, how Life Cycle Assessment works, and their achievement so far.

\section{k. Heading Tags}

Heading tags' purpose is to inform the content of the page to the users [25]. The applications of heading tags are based on their brand and their services, the main focus, which is Life Cycle Assessment (LCA). So, the appropriate heading tags for Ailesh Green Consulting are "Ailesh Green Consulting Life Cycle Assessment (LCA) Consulting”.

\section{l. Keyword Placement}

Keyword placement is one of the most important factors to put the website to get a higher ranking in the search result [25]. The goal is to develop a highly relevant page by placing the keyword on the strategic places on the web page. There are several places to put the keyword, based on [27]:

i) Place keywords in the title tag, description meta tag, and headings. ii) Place keywords in the first and the last paragraph.

iii) Bold, underline, and italicize the target keywords at least once on the page.

\section{2) Off-Page Optimization}

\section{a. Sharing}

The way developers share all information about their website to increase the popularity [25]. Create shareable content, so readers can share the information with their relatives or anyone they think matches the content. Content shareable: How to use the LCA, the information about LCA, Why LCA is important.

\section{b. Blog-Commenting}

The blogs or posts that get a lot of likes and comments will increase the ranking in search results [25]. With content that is shareable and interesting to the reader, it will appear comments from readers.

\section{c. Star Rating}

Posts that have a lot of likes and star ratings will have a high ranking on google [25]. The content presented must be quality, not contain incorrect or unfounded information, and help answer many people's questions. Content: Government's new policy on Life Cycle Assessment.

\section{d. Link Building}

If many websites have links to a certain website, the search engine will finds the chosen website [25]. By becoming one of the websites that provide information about Life Cycle Assessment, there will be many other websites that refer to Ailesh Green Consulting as a reference consultant and the latest information life cycle assessment.

\section{3) Key Performance Indicators of Search Engine Optimization}

There are several ways to measure the Search Engine Optimization based on [28]:

a. Audience: shows how much traffic on the website and the demographic of the visitors.

- Average session duration;

- Bounce rate;

- Sessions;

- Page/ sessions.

b. Acquisitions: shows how many users coming from each channel (organic, search, paid search, direct, email, and social sources).

- Top channels.

c. Behaviour: indicates what the visitors do on the website. Behavior gives information about how visitors navigate on the pages and how they react to the content.

- Average Time on Page;

- Page views;

- Top exit pages;

- Checkout funnel.

d. Conversion: anything that company want the visitors to execute, like signing the email or fill the registration forms.

\section{- Conversions}

\section{B. Display Advertising - LinkedIn Ads}

LinkedIn is a platform for professionals who offer LinkedIn ads, which is a paid ad that will appear in the 
timeline of its users. According to 2018 data, $65 \%$ of B2B marketers have acquired their customers by using LinkedIn ads [29].

\section{1) Sponsored Content}

\section{a. Single Image Ads}

Single image ads appear on the homepage of customers who want to be achieved, can be in the form of a desktop or in the website. The application for single image ads is Ailesh Green Consulting featuring the plants that have been done, one of the thirteen plants that have been analyzed with LCA, with a caption explaining that Ailesh Green Consulting already has experience in the work of Life Cycle Assessment with a duration of 3 months. With the appearance of these ads in the feed of potential customers, it will be possible for them to visit Ailesh Green Consulting's LinkedIn profile because it suits their needs, namely life cycle assessment consulting services.

\section{b. Video Ads}

Video ads have similarities to single image ads, which appear on the homepage of the customers they want to achieve, but video ads have some special specifications that must be met based on [30]. The concept of video ads is the same as the concept in single image ads, which shows the achievements of Ailesh Green Consulting.

\section{2) Dynamic Ads}

\section{a. Followers Ads}

Encourage members to follow the LinkedIn Page or Showcase Page. Tailored to each member as they feature their profile picture photos next to the brand logo, plus their first name and the company name in the ad copy. The descriptions are "Get your Life Cycle Assessment with us!" and the headlines is "now it's your turn to use our best services, Life Cycle Assessment"

\section{b. Spotlight Ads}

Ads that are personalized to each LinkedIn member and take them to the brand's landing page. The ads are seen on desktop and tailored to individual members based on their data on LinkedIn [31]. The headline is "Now it's your turn to find out the best consultant in Life Cycle Assessment at Ailesh Green Consulting", with the landing page is the website of Ailesh Green Consulting.

\section{3) Text Ads}

Text ads included a headline, brief text, and an image. They may be placed at the top of the page or in the right rail of a variety of LinkedIn desktop pages [32]. The image is a logo of Ailesh Green Consulting, the headline is "Do your Life Cycle Assessment with us!", descriptions "We provide life cycle assessment analysis calculation conducted by young Indonesians who are professionals, and we can finish it faster than others!" with the destinations is a website of Ailesh Green Consulting.

\section{4) Key Metrics for LinkedIn Ads}

The key matric for LinkedIn Ads is focused on the create brand awareness of Ailesh Green Consulting, few metrics should be focused on [33]:

- Clicks;

- Impressions;

- Click-Through Rate (CTR);

- Average engagement.

\section{Social Media Marketing - LinkedIn}

Ailesh Green Consulting is able to find potential partners and potential customers that match their target market, companies that need LCA services, especially companies included in the gold criteria by PROPER Indonesia in LinkedIn because LinkedIn is a suitable medium for the professional network, strengthening the business relationships and support careers [34].

\section{1) Company Page}

A company page is to connect and interact with the audience both from employees and people on LinkedIn. Based on [35] there are few steps to conduct company page:

a. Company description: Ailesh Green Consulting is a business unit in the field of environmental impact control and improvement consulting services to assists partner companies in achieving sustainability aspects, both in terms of planning, calculation \& assessment, compilation \& mentoring of environmental programs. Speciality: LCA consulting, Life Cycle Assessment, renewable energy, LCA services, Life Cycle.

b. Upload media: Project that has been done by Ailesh Green Consulting, which is 13 units of power plants from Banten to West Nusa Tenggara.

c. Create a profile in a different language: Ailesh Green Consulting's LinkedIn page uses two different languages, Indonesian and English. This is to make it easier for potential customers to understand Ailesh Green Consulting with their language.

2) Post

The second thing to discuss is posts on LinkedIn. Here are some steps to optimize posts on LinkedIn based on [35]:

a. Adding hashtags to post: the hashtags the corresponds to Ailesh Green Consulting are Life Cycle Assessment, Life Cycle Assessment Services, Life Cycle Assessment Consulting.

b. Interaction with the costumers: create a content that invites the reader to interact with the business, the interesting content will raise questions and reactions from visitors, whether in the forms of likes, shares, or even comments.

c. Time to post: the applications are weekdays (Monday to Friday) with post hours at 8 a.m. and 10 a.m.

\section{3) Message}

The LinkedIn posting is based on three categories of message content, based on company values and customer involvement, a) product-oriented messages, b) value-based messages, c) action-oriented messages [36].

a. Product-oriented messages: Explain about the product presented by Ailesh Green Consulting, promoted by the face of the business, such as CEO, which aims to make the product speak and alive.

b. Value-based messages: This post is to explain more about the value held by Ailesh Green Consulting in carrying out its business activities. Ailesh Green Consulting talked about their company which is filled with young people who are fully dedicated to the environment, have professional skills in the field of LCA. The post is a short video about Ailesh Green Consulting which implies the meaning that Ailesh Green Consulting as one of the startup subsidiaries that cares about the environment and can work professionally. 
c. Action-oriented messages: This post is to encourage people or readers to do some actions and their involvement. Post something that is being talked in the moment and do the analysis of the situation life cycle assessment that attracts readers to comment and argue in a good way.

\section{4) Key Performance Indicators for LinkedIn}

There are several KPI to measure the brand awareness and customer purchase intention based on [37]:

- Number of followers on LinkedIn business pages;

- Number of daily unique visitors on average;

- Number of page views;

- Number of qualified leads from lead-generation offers;

- Number of qualified leads from reaching out.

\section{Content Marketing - Website}

1. Content marketing has improved the hit rate (probability of turning a prospect into a qualified lead) up to $30 \%$ [38]. In this business solution, the author uses B.E.S.T. formula to create a content marketing roadmap, it is useful to look at the critical moment and to determine the strategy [39].

2. Behavioral: What consumers feel when visiting the content website of Ailesh Green Consulting is satisfied because of the information he gets and feels that Ailesh Green Consulting is one of the reliable sources of information for Life Cycle Assessment related content. The action that is expected to be taken from consumers is to share content from Ailesh Green Consulting on their social media so that the information provided by Ailesh Green Consulting can be spread. With useful information and relate to consumers, it is expected that they have the desire to use Ailesh Green Consulting in the future and make Ailesh Green Consulting one of the environmental consultants that are considered.

3. Essential: Consumers need information related to life cycle assessment, why it is important for a company to do, and the advantages provided by Ailesh Green Consulting that have a big impact for its consumers, such as faster uptime so that companies can get reports faster for the overall Life Cycle Assessment. By providing content that addresses this, such as that the government already requires companies to conduct Life Cycle Assessment and the impact that can be given to companies, the environment, and government will provide more understanding and knowledge to consumers so that they are interested in using Life Cycle Assessment for their companies. Based on [38] the type of media that is the most effective is visual content such as photos, infographics, and videos. Based on this, the use of videos and photos is important to put in content marketing, to give an overview to consumers about the Life Cycle Assessment, the process of workmanship, and how it can have a broad impact on all aspects.

4. Strategic: The content provides information about life cycle assessment, namely the way of Life Cycle Assessment done, fast working time of Ailesh Green Consulting to provide Life Cycle Assessment, the advantages of companies that relate to the needs of consumers, this increases the possibility of consumers to use the services of Ailesh Green Consulting. This is in accordance with the goal of using content marketing, which is to increase customer purchase intention and brand awareness.

5. Targeted: The target of Ailesh Green Consulting content is potential buyers, the companies that use Life Cycle
Assessment as one of their company's mandatory assessments. Providing content with a point of view as a person who needs a Life Cycle Assessment, will provide an interesting point of view of a content because consumers will feel that indeed the content in Ailesh Green Consulting is the content they need to choose a company in the field of Life Cycle Assessment.

- Key Performance Indicator of Content Marketing Website

Based on [38] there are several ways of KPI for content marketing using websites. There are:

- Visitors per segment on the website.

- Cost per visit by the visitors.

- Number of Likes, comments, share/ re-blog on the content of the website.

- A number of mentions of the website by the other blogs or on another social media.

\section{CONCLUSION}

The problems faced by Ailesh Green Consulting are brand awareness and customer purchase intention; the result is based on an interview with the Chief of Business Operation of Ailesh Power, who is also in control of Ailesh Green Consulting, as well as the results of interviews with potential customers who stated that they do not know Ailesh Green Consulting and have no interest in using the services of Ailesh Green Consulting.

The existing digital marketing strategy used is a website, and promotions used are still based on word of mouth, and personal selling has not used digital marketing. Ailesh Green Consulting currently only uses website media as a digital marketing platform, which has not been adequately optimized because it contains only superficial information about the companies and services served. The use of digital marketing can help the issue faced by Ailesh Green Consulting, content marketing for the website, Search Engine Optimization, social media marketing with optimizing the use of LinkedIn, display advertising with LinkedIn ads.

\section{REFERENCES}

[1] D. Chaffey and F. E. Chadwick, Digital Marketing Strategy, Implementation and Practice, United Kingdom: Pearson Education Limited, 2016.

[2] APJII, "Laporan Survei Internet APJII 2019 - 2020 [Q2]," APJII, 2020.

[3] Elfo, "bahwa belanja iklan digital di Indonesia melalui iklan baris seperti iklan video, iklan media sosial, iklan banner, iklan pencarian meningkat pada tahun 2020 akibat dampak Covid-19, diperkirakan akan meningkat sekitar Rp 21 miliar atau meningkat 15,15\% ye," Elfo, $92020 . \quad$ June 20 Online]. Available: https://www.elfo.com/newsroom/digital-marketing-di-era-pandemi/.

[4] MTarget, "Insight Email Marketing di Indonesia Berdasarkan Industri," 14 July 2020. [Online]. Available: https://blog.mtarget.co/insight-email-marketing-di-indonesiaberdasarkan-industri/.

[5] AMA, "What is Digital Marketing?," 2021. [Online]. Available: https://www.ama.org/pages/what-is-digital-marketing/.

[6] P. Mandal and N. Joshi, "Understanding Digital Marketing Strategy," International Journal of Scientific Research and Management (IJSRM), pp. 5428-5431, 2017. 
[7] R. Berman and Z. Katona, "The Role of Search Engine Optimization in Search Marketing," Marketing Sciene, pp. 644-651, 2013.

[8] M. S. Kittur and K. M. Mane, "A Study on Use of Search Engine Optimization with Reference to Sarvana Paints, Kolhapur," International Journal of Trend in Scientific Research and Development (IJTSRD), pp. 218-219, 2019.

[9] S. N. Srivastava, S. Kshatriya and R. S. Rathore, "Search Engine Optimization in E-Commerce Sites," International Research Journal of Engineering and Technology (IRJET), pp. 153-155, 2017.

[10] S. Kingsnorth, Digital Marketing Strategy: An Integrated Approach to Online Marketing, Great Britain and the United States : Kogan Page Limited, 2016.

[11] F. Cizmeci and T. Ercan, "The Effect of Digital Marketing Communication Tools in," Megaron, pp. 149-161, 2015.

[12] R. S. Bhandari and A. Bansal, "Impact of Search Engine Optimization as a Marketing Tool," Jindal Journal of Business Research, pp. 24-36, 2018.

[13] Ahmed, R. Raheem, J. Vveinhardt and D. Streimikiene, "Interactive digital media and impact of customer Interactive digital media and impact of customer Interactive digital media and impact of customer," ournal of Business Economics and Management, p. 1115-1134, 2017.

[14] Krishnaprabha and Tarunika, "An Analysis on Building Brand Awareness through Digital Marketing Initiatives," International Journal of Research in Engineering, Science and Management, 2020.

[15] P. Laksamana, "Impact of Social Media Marketing on Purchase Intention and Brand Loyalty: Evidence from Indonesia's Banking Industry," International Review of Management and Marketing, vol. 8, no. 1, pp. 13-18, 2018.

[16] A. J. Kim and E. Ko, "Impacts of Luxury Fashion Brand's Social Media Marketing on Customer Relationship and Purchase Intention," Journal of Global Fashion Marketing, pp. 164-171, 2012.

[17] G. Holliman and J. Rowley, "Business to business digital content marketing: marketers' perceptions of best practice," Journal of Research in Interactive Marketing, 2014.

[18] D. Chaffey, "Introducing The RACE Framework: a practical framework to improve your digital marketing," 17 May 2021. [Online]. Available: https://www.smartinsights.com/digitalmarketing-strategy/race-a-practical-framework-to-improve-yourdigital-marketing/.

[19] C. Campbell, J. Cohen and J. Ma, "A new Typology for Evolving Forms of Online "advertising"," Journal of Advertising Research, pp. 7-10, 2014.

[20] M. Switala, K. Reformat, B. Reformat and W. Gamrot, "The Influence of Brand Awareness and Brand Image on Brand Equity - an Empirical Study of Logistic Service Provider," Journal of Economics and Management, pp. 96-119, 2018.

[21] W. Romaniuk and M. Faulkner, "Brand awareness : revisiting an old metric for a new world," Journal of Product \& Brand Management, pp. 469-476, 2017.

[22] Z. h. T. Shahid and a. Fareeh, "The Impact of Brand Awareness on The Consumer's Purchase Intention," Journal of Marketing and Consumer Research, 2017.

[23] M. Shabbir, A. Khan and S. Khan, "Brand Loyalty Brand Image and Brand Equity : The Mediating Role of Brand Awareness," International Journal of Innovation and Applied Studies, pp. 416-423, 2017.

[24] P. Kotler and G. Arsmstrong, Principles of Marketing, United Kingdom: Pearson Education Limited, 2018.

[25] P. Kotler and K. L. Keller, Marketing Management, England: Pearson Education Limited, 2016.

[26] S. Reeves, M. Albert, A. Kuper and B. Hodges, "Why use theories in qualitative research?," BMJ, 2008.

[27] B. Stenerson, "Integrating qualitative and quantitative theoretical perspectives in applied advertising research," Journal of Business Research, p. 431-433, 2008.

[28] P. Swati, B. Pawa and P. A. S, "Search Engine Optimization: A Study," Research Journal of Computer and Information Technology Sciences, pp. 10-13, 2013.

[29] D. Sharma, A. Giri, S. Rishabh and S. Kumar, "A brief review on search engine optimization," in 9th International Conference on Cloud Computing, Data Science \& Engineering, 2019.
[30] A. Veglis, "Employing Search Engine Optimization Techniques in Online News Articles," Studies in Media and Communication, vol. 3, no. 1, June 2015.

[31] E. Ochoa, "An Analysis of The Application of Selected Search Enine Optimization (SEO) Technique and Their Effectiveness on Google's Search Ranking Algorithm," California State University, pp. 34-40, 2012.

[32] K. Rojalin, "Search Engine Optimization for an International Business to Business Company in the Beauty Industry," jamk.fi, 2020.

[33] I. Belogolovsky, "The Guide to LinekdIn Ads," [Online]. Available: https://neilpatel.com/blog/guide-to-linkedin-ads1/.

[34] LinkedIn, "Video Ads - Advertising Specifications," February 2021. [Online]. Available: https://www.linkedin.com/help/lms/answer/a424737.

[35] LinkedIn, "Dynamic Ads - Advertising Specifications," February 2021. [Online]. Available: https://www.linkedin.com/help/lms/answer/a420342.

[36] LinkedIn, "Text Ads - Advertising Specifications," 2021. [Online]. Available: https://www.linkedin.com/help/lms/answer/a423705.

[37] B. LinkedIn, "Analyze your Campaign Performance," 2021. [Online]. Available: https://business.linkedin.com/marketingsolutions/success/best-practices/analyze-your-performance.

[38] LinkedIn, "What is LinkedIn and How Can I Use It?," 2020. [Online]. Available: https://www.linkedin.com/help/linkedin/answer/111666/apa-itulinkedin-dan-bagaimana-cara-menggunakannya-?lang=en.

[39] D. B. Academy, Social Media Marketing 2021-22, Digital Business Academy, 2021.

[40] M. Sundström and K. Alm, "B2B social media content: engagement on LinkedIn," Journal of Business \& Industrial Marketing, 2020.

[41] B. B. Reis, "LinkedIn as a Marketing Tool for Lead Generation in B2B Organizations," NOVA Information Management School, 2018.

[42] D. L. M, "Content Marketing," University of Applied Sciences, 2013.

[43] J. Pulizzi and N. Barrett, "Get Content Get Customers," in Get Content Get Customers, United States, Mc Graw Hill, 2009, p. 36.

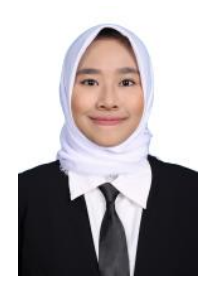

Dwiana Rahmadiati Putri graduated from Universitas Pembangunan Nasional "Veteran" Yogyakarta in 2019. She pursued master's degree in Institut Teknologi Bandung (ITB) focus on marketing. She is interested in digital marketing, market research, and branding. 